\title{
Distribution of Enterobius vermicularis and biochemical analysis of parasitosis primary school student
}

\section{IIlköğrretim okulu çocuklarında Enterobius vermicularis dağılımı ve parazitozun biyokimyasal analizi}

*Serpil Değerli, **Ahmet Kuzu

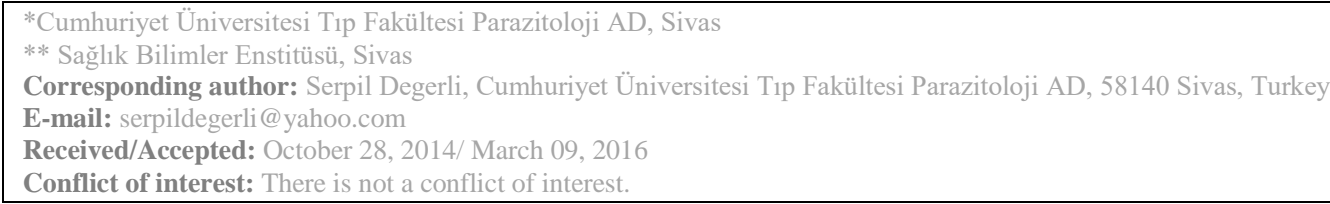

\section{SUMMARY}

Objective: This study was made in two Primary School, which is in Kocaeli city Derince. The aim of this study was to detect of Enterobius vermicularis (oxyuris) prevelance and relation of bloods which taken from children with made biochemical parameters by biochemical analysis

Method: In this study, which was made selophan band method.

Results: At study, E. vermicularis spawn have been found at 20 of 722 students $(2,8 \%)$, and $E$. vermicularis spawn have been not found at 702 students $(97,2 \%)$. It's 9 are male $(49,7 \%)$ and 11 are female $(50,3 \%)$. Study have been realised 7 to 15 ages and it have been fixed to more often of parasite prevelance with 3,6\% 7 to 9 ages. But this situation have not been logical by statistically. When compaired height and weight of students, statistically a clear difference have been found. The student E.vermicularis have been detected, eosinophil values clearly high and HCT values detected low and this situation have been found logical statistically $(\mathrm{p}=0,000, \mathrm{p}<0,05)$.

Conclusions: Enterobiosis is still the most common parasitic diseases in children.

Keywords: Kocaeli, cellophane band, Enterobius vermicularis, socio-economical status, biochemical analysis.

\section{ÖZET}

Amaç: Bu çalışmada, Kocaeli İlinin Derince İlçesindeki iki ilköğretim okulundaki Enterobiyoz dağılımının saptanması ve enterobiyozlu çocukların kan örneklerinin biyokimyasal analizlerini yaparak biyokimyasal parametrelerle enterobiyozis arasındaki ilişkinin ortaya konması amaçlanmıştır.

Yöntem: Araştırmada 722 öğrenciden alınan selofanbant örnekleri incelenmiştir.

Bulgular: 722 öğrencinin 20'sinde (\%2,8) E. vermicularis yumurtasına rastlanılmıştır. Pozitif saptanan olguların 9'u $(\% 49,7)$ erkek, 11 'i $(\% 50,3)$ kızdır. Araştırma 7-15 yaş aralığında gerçekleştirilmiş olup parazit prevalansının \%3,6 ile 7-9 yaş grubunda daha sık görüldüğü saptanmıştır. Öğrenciler boy ve kilolarına göre karşılaştırıldığında E.vermicularis görülen ve görülmeyen öğrenciler arasında belirgin oranda bir fark gözlenmiş ve istatistiksel olarak anlamlı bulunmuştur. Öğrenciler sosyoekonomik durumlarına göre E. vermicularis görülme sılkl̆ğ1 yönünden karşılaştırılmış ve istatistiksel olarak anlamlı bir fark bulunmuştur $(p=0,000 \mathrm{p}<0,05)$. Enterobiyozlu çocuklarda en sık rastlanan klinik semptom ağızdan salya akması olmuştur. E. 


\begin{abstract}
vermicularis yumurtası saptanan öğrencilerde eozinofil değerleri belirgin oranda yüksek çıkmış ve HCT değeri düşük çıkmış bu durum istatistiksel olarak anlamlı bulunmuştur.

Sonuç: İlköğretim çağı çocuklarında enterobiyoz hala en s1k görülen parazitoz olarak saptanmaktadır

Anahtar sözcükler: Kocaeli, selofan bant, Enterobius vermicularis, sosyo-ekonomik durum, biyokimyasal analiz.
\end{abstract}

\section{INTRODUCTION}

Intestinal parasites has important place in infection diseases in all the world and our country ${ }^{1}$. Intestinal parasite infections that change linked with social, cultural, ecologic and hygienic differences is an important healthy problem especially affect to developing countries. It is announced intestinal parasites that are thought about enfect to about 2 billion people in the world don't change too much in parallel increasing population since half century despite economic, medical and technological developments, infection proportion reaches to percent ninty in some endemic countries ${ }^{2,3}$.

Children are the most important infectious source for E.vermicularis that is established in first line in intestinal parasites and is belonging to nematod category with other name oxyuris. In the world appearing enterobiosis frequency that is usually seen in preschool and primary children and mild climate changes between 2$42 \%$. Intestinal parasitosis frequency reveals high prevalence in Turkey even if reasons as geographical climate and ecological conditions, education and cultural level, custom and habits, absence of cleanliness, not healthy environment conditions are in different proportions and values ${ }^{5}$.

Many of intestinal parasites can be determined by feces examine. Yet 1-5\% of enterobiosis can be recognized with this search because E.vermicularis that its female lays eggs in perianal region. Examination of perianal region material (PABM) is need for diagnosis of this parasitosis. PABM is usually taken with cellophane tape method ${ }^{6}$.

In this study it was aimed that distribution of E.vermicularis in two primary schools students who have different socioeconomic situation determined in Kocaeli, factors that affect this and comparison of biochemical analysis of blood samples which are take from children enterobiosis and not children enterobiosis.

\section{MATERIAL AND METHODS}

Bekir Sitkı Özer Primary School which most of them are civil servant children and students who have good socioeconomic situation is located in Provincial Police Directory Residences in Derince borough of Kocaeli Province and Kocaeli Teachers Primary School in Derince borough Yenikent District have been included in this research. Presence of E.vermicularis parasite has been investigated with cellophane tape methode in 722 students which occurs from 497 students from 7-15 years old in Bekir Sitkı Özer Primary School and 1st to 8th class students study and 225 students in Kocaeli Teachers Primary School.

In study confirmation has been taken from Derince borough and Derince borough National Education Directory. Information was given about parasites and parasite infections to school teachers and students before study. A envelope was given to all of students in the schools in the scope of work. Slide on which cellophane tape was pasted, a card which talks about how cellophane band method applies and survey which organizes to be filled writing students' names were placed and distributed giving to guardians for their applications.

There are vaious questions in questionaire for examples; name, surname, class, school, date of birth, sex, weight, height, place where their family live, the number of rooms and members in the house, the total of family's income, school success, mother's working status, parasite treating or not, information about parasites or not vs.

Cellophane tape which were collected from students were examined directly in light microscopy in Police Clinic Laboratuary at Provincial Police Directory and in Parasitology Department in Medicine Faculty at Cumhuriyet University. In the end of examine, students who have E.vermicularis egg were reached by within school management 
acknowledge, were wanted to go to the Derince Dumlupinar Health Center and biochemical results were obtained from blood samples which were taken from students here. Also a control group of healthy students with regard to parasite was created and these students were brought to healthy clinic and blood samples were taken and biochemical results were obtained and were evaluated statistically.

Biochemical results of taking blood samples were obtained to be used with Brand BD Vacutainer blood collection tubes in vacuum in the Siemens Dade Behring Device. Blood count tests were worked by the Brand BD Vacutanier tubes in Pentra 80 Device.

SPSS for Windows Program in 13 was used for evaluating of data statistically. Student T-test was used for comparing length and kilo of group in enterobiosis and not enterobiosis. Nonparametric Mann-Whitney test was used in comparison of blood count and biochemistry values owing to there are below 30 people in group.

Because all of data like age, the number of rooms and members in the house, sex, place where their family live, income level, the success, working situation of mother, to be treated or not, abdominal pain, itching, dropping ring, flowing saliva, habit of biting nail, dental grinding, nocturnal enuresis, dysuria, diarrhea, eating soil, eating ash, habit of eating ice, loss of appetite were obtained by sorter scale, chi-square test was used in comparison of these data. And all of evaluation was done in level of 0.05 error. After working families of children who have parasites were informed and they were ensured to begin to necessary treatment.

\section{RESULTS}

Cellophane band examples which were taken 722 students who is total of 497 from Bekir Sitk1 Özer Primary School and 225 from Kocaeli Teachers Primary School examined in our study. In the end of examination Enterobius vermicularis egg was seen in total 20 children which have $9(49.7 \%)$ male and 11 $(50.3 \%)$ female. While prevalence of parasite was $3.6 \%$ at Bekir Sitk1 Özer School, prevalence of parasite was $0.9 \%$ at Kocaeli Teachers School when two schools were compaired (Table 1).

Table 1. Distribution of Enterobiosis in two pimary school in children

\begin{tabular}{|c|c|c|c|c|c|c|c|}
\hline \multirow[b]{2}{*}{ School } & \multicolumn{2}{|c|}{$\begin{array}{l}\text { Group with } \\
\text { enterobiosis }\end{array}$} & \multicolumn{2}{|c|}{$\begin{array}{c}\text { Group with non } \\
\text { enterobiosis }\end{array}$} & \multicolumn{2}{|c|}{ Total } & \multirow{2}{*}{$\begin{array}{c}\text { Statistical } \\
\text { analysis }\end{array}$} \\
\hline & n & $\%$ & $\mathbf{n}$ & $\%$ & $\mathbf{n}$ & $\%$ & \\
\hline $\begin{array}{l}\text { Bekir Sıtkı } \\
\text { Özer }\end{array}$ & 18 & 3,6 & 479 & 96,4 & 497 & 68,9 & \multirow{3}{*}{$\begin{array}{l}\chi^{2}=4,295 \\
p=0,038\end{array}$} \\
\hline $\begin{array}{c}\text { Kocaeli } \\
\text { Öğretmenler }\end{array}$ & 2 & 0,9 & 223 & 99,1 & 225 & 31,1 & \\
\hline Total & 20 & 2,8 & 702 & 97,2 & 722 & 100 & \\
\hline
\end{tabular}

When to distribution of Enterobius vermicularis was revealed in according to school, it was found statistically significant differance $(p<0,05)$. The prevalence of parasite according to sex were given at Table 2 in which there were $363 \quad(\% 50,3)$ female and 359 male students. 
Table 2. Distribution of E.vermicularis to gender in children

\begin{tabular}{|c|c|c|c|c|c|c|c|}
\hline \multirow[b]{2}{*}{ Gender } & \multicolumn{2}{|c|}{$\begin{array}{l}\text { Group with } \\
\text { enterobiosis }\end{array}$} & \multicolumn{2}{|c|}{$\begin{array}{l}\text { Group with } \\
\text { nonenterobiosis }\end{array}$} & \multicolumn{2}{|c|}{ Total } & \multirow{2}{*}{$\begin{array}{c}\text { Statistical } \\
\text { analysis }\end{array}$} \\
\hline & n & $\%$ & n & $\%$ & $\mathbf{n}$ & $\%$ & \\
\hline Boy & 9 & 2,5 & 350 & 97,5 & 359 & 49,7 & \multirow{3}{*}{$\begin{array}{l}\chi^{2}=0,184 \\
p=0,688\end{array}$} \\
\hline Girl & 11 & 3 & 352 & 97 & 363 & 50,3 & \\
\hline Total & 20 & 2,8 & 702 & 97,2 & 722 & 100 & \\
\hline
\end{tabular}

Parasite frequency was identified 2,5\% in male and $3 \%$ in female. There was not statistically significant differance in distribution of E.vermicularis according to sex $(\mathrm{p}=0,688, \mathrm{p}>0,05)$.

The study was realised in the range of 7-15 age and students were divided to 3 different age groups. In 7-9 age group $49.4 \%$, in 10-12 age group $38.8 \%$ of children, in $13-15$ age $11,8 \%$ group of children were included. Distribution in age groups and statistically in the range of E.vermicularis frequencywas revealed at Table. 3

Table 3. Distribution of E. vermicularis to age in children

\begin{tabular}{|c|c|c|c|c|c|c|c|}
\hline \multirow{2}{*}{ Age } & \multicolumn{2}{|c|}{$\begin{array}{l}\text { Group with } \\
\text { enterobiosis }\end{array}$} & \multicolumn{2}{|c|}{$\begin{array}{c}\text { Group with } \\
\text { nonenterobiosis }\end{array}$} & \multicolumn{2}{|c|}{ Total } & \multirow{2}{*}{$\begin{array}{l}\text { Statistical } \\
\text { analysis }\end{array}$} \\
\hline & $\mathbf{n}$ & $\%$ & $\mathbf{n}$ & $\%$ & $\mathbf{n}$ & $\%$ & \\
\hline $7-9$ & 13 & 3,6 & 344 & 96,4 & 357 & 49,4 & \multirow{4}{*}{$\begin{array}{l}\chi^{2}=2,069 \\
p=0,355\end{array}$} \\
\hline $10-12$ & 5 & 1,8 & 275 & 98,2 & 280 & 38,8 & \\
\hline $13-15$ & 2 & 2,4 & 83 & 97,6 & 85 & 11,8 & \\
\hline Total & 20 & 2,8 & 702 & 97,2 & 722 & 100 & \\
\hline
\end{tabular}

According to results at Table 3, students were divided to 7-9, 10-12, 13-15 age groups and despite there was not statistically significant differance in age groups $(\mathrm{p}=0,355, \mathrm{p}>0,05)$ in the range of E.vermicularis frequency, parasite frequency was found to be highest in 7-9 age group (3.6\%). 
Table 4. The results of children with group enterobiosis and non enterobiosis to weight and height

\begin{tabular}{|c|c|c|c|c|c|}
\hline & & $\begin{array}{l}\text { Group with } \\
\text { enterobiosis }\end{array}$ & $\begin{array}{c}\text { Group with } \\
\text { nonenterobiosis }\end{array}$ & Total & $\begin{array}{c}\text { Statistical } \\
\text { analysis }\end{array}$ \\
\hline Weight & $\begin{array}{c}\text { average } \pm \\
\text { Std.D. }\end{array}$ & $28,3 \pm 4,9$ & $32,1 \pm 8,4$ & $32,0 \pm 8,3$ & $\begin{array}{l}\mathrm{t}=2,04 \\
\mathrm{p}=0,04\end{array}$ \\
\hline Height & $\begin{array}{c}\text { average } \pm \\
\text { Std.D. }\end{array}$ & $130,3 \pm 8,6$ & $136,7 \pm 11,3$ & $136,5 \pm 11,3$ & $\begin{array}{l}t=2,47 \\
p=0,01\end{array}$ \\
\hline
\end{tabular}

Comparison of students who participate in to study in the range of weight and height was revealed.
When students were compaired according to their weight and height, it was found significant to be statistically difference $(\mathrm{p}=0,04, \mathrm{p}<0,05)($ Table 4$)$.

Table 5. Distribution of E. vermicularis to socio- economical status of family

\begin{tabular}{|c|c|c|c|c|c|c|c|}
\hline \multirow{2}{*}{$\begin{array}{l}\text { Income } \\
\text { (TL) }\end{array}$} & \multicolumn{2}{|c|}{$\begin{array}{l}\text { Group with } \\
\text { enterobiosis }\end{array}$} & \multicolumn{2}{|c|}{$\begin{array}{c}\text { Group with } \\
\text { nonenterobiosis }\end{array}$} & \multicolumn{2}{|c|}{ Total } & \multirow{2}{*}{$\begin{array}{c}\text { Statistical } \\
\text { analysis }\end{array}$} \\
\hline & $\mathbf{n}$ & & & & $\mathbf{n}$ & $\%$ & \\
\hline $0-750$ & 9 & 10,8 & 74 & 89,2 & 83 & 11,5 & \multirow{4}{*}{$\begin{aligned} \chi^{2} & =24,394 \\
p & =0,000\end{aligned}$} \\
\hline $750-1500$ & 7 & 2,8 & 246 & 97,2 & 253 & 35 & \\
\hline up 1500 & 4 & 1 & 382 & 99 & 386 & 53,5 & \\
\hline Total & 20 & 2,8 & 702 & 97,2 & 722 & 100 & \\
\hline
\end{tabular}

When students who participate in to study have been compaired according to their socioeconomic situation, distribution of parasite has been revealed (Table 5).

When students have been compaired according to their socioeconomic situation, there was statistically significant difference in the range of E.vermicularis frequency $(\mathrm{p}=0,000, \mathrm{p}<$ 0,05). It was found low of E.vermicularis frequency as increasing income level.

Situation of school success in students with group Enterobiosis and not who participated in to study has been compaired at Table 6 . 
Table 6. Distribution of students to school success

\begin{tabular}{|c|c|c|c|c|c|c|c|}
\hline \multirow[t]{2}{*}{$\begin{array}{l}\text { School } \\
\text { success }\end{array}$} & \multicolumn{2}{|c|}{$\begin{array}{l}\text { Group with } \\
\text { enterobiosis }\end{array}$} & \multicolumn{2}{|c|}{$\begin{array}{l}\text { Group with } \\
\text { nonenterobiosis }\end{array}$} & \multicolumn{2}{|c|}{ Total } & \multirow{2}{*}{$\begin{array}{c}\text { Statistical } \\
\text { analysis }\end{array}$} \\
\hline & n & $\%$ & $\mathbf{n}$ & $\%$ & n & $\%$ & \\
\hline 1 & 0 & 0 & 12 & 100 & 12 & 1,6 & \multirow{6}{*}{$\chi^{2}=31,610$} \\
\hline 2 & 5 & 11,4 & 39 & 88,6 & 44 & 6,1 & \\
\hline 3 & 10 & 7,8 & 119 & 92,2 & 129 & 17,9 & \\
\hline 4 & 4 & 1,5 & 271 & 98,5 & 275 & 38 & \\
\hline 5 & 1 & 0,4 & 261 & 99,6 & 262 & 36,4 & \\
\hline Total & 20 & 2,8 & 702 & 97,2 & 722 & 100 & \\
\hline
\end{tabular}

When group with enterobiosis and non enterobiosis according to their success situation has been compaired, the difference was found significant to be statistically $(\mathrm{p}=0,000, \mathrm{p}<0,05)$. It was found low that success status of students with Enterobiosis.

Students who have been taken into scope of the research have been grouped according to number of room and person, place where their family live and working status of their mothers. The number of rooms was 3 low in their houses in distribution of the number of room and this situation was found significant to be statistically $(\mathrm{p}=0,004 \mathrm{p}<0,05)$.
It was found that parasite frequency increased as number of person living at home increased and this situation was found significant to be statistically $(\mathrm{p}=0,003 \mathrm{p}<0,05)$. The number of people in their house of 13 of 30 students enterobiosis is 5-9.

Revealing clinic symptoms as abdominal pain, anal itching, saliva flowing, dropping ring, habit of biting nail, habit of dental grinding, nocturnal enuresis, dysuria, anorexia in children has been summarized at Table 7 . 
Table 7. Clinical semptomps between children with enterobiosis and non enterobiosis $(n=722)$

\begin{tabular}{|c|c|c|c|c|c|c|c|c|}
\hline \multirow{4}{*}{$\begin{array}{c} \\
\begin{array}{c}\text { Previously } \\
\text { treatment } \\
\text { from } \\
\text { parasitosis }\end{array}\end{array}$} & \multirow[b]{3}{*}{ yes } & \multirow{2}{*}{\multicolumn{2}{|c|}{$\begin{array}{c}\text { with } \\
\text { enterobiosis } \\
\%\end{array}$}} & \multicolumn{2}{|c|}{ non enterobiosis } & \multicolumn{2}{|c|}{ Total } & \multirow{2}{*}{$\begin{array}{c}\text { Statistical } \\
\text { analysis }\end{array}$} \\
\hline & & & & $\mathbf{n}$ & $\%$ & $\mathbf{n}$ & $\%$ & \\
\hline & & 1 & 1,4 & 71 & 98,6 & 72 & 10 & \multirow{2}{*}{$\begin{array}{l}\chi^{2}=0,566 \\
p=0,452\end{array}$} \\
\hline & no & 19 & 2,9 & 631 & 97,1 & 650 & 90 & \\
\hline \multirow{2}{*}{$\begin{array}{c}\text { Knowledge } \\
\text { about } \\
\text { parasites }\end{array}$} & yes & 3 & 2,1 & 138 & 97,9 & 141 & 19,5 & \multirow{2}{*}{$\begin{array}{l}\chi^{2}=0,268 \\
p=0,604\end{array}$} \\
\hline & no & 17 & 2,9 & 564 & 97,1 & 581 & 80,5 & \\
\hline \multirow{2}{*}{$\begin{array}{l}\text { Abdominal } \\
\text { pain }\end{array}$} & yes & 7 & 5,8 & 113 & 94,2 & 120 & 16,6 & \multirow{2}{*}{$\begin{aligned} \chi^{2} & =5,014 \\
p & =0,025\end{aligned}$} \\
\hline & no & 13 & 2,2 & 589 & 97,8 & 602 & 83,4 & \\
\hline \multirow{2}{*}{ Itching } & yes & 3 & 4,2 & 69 & 95,8 & 72 & 10 & \multirow{2}{*}{$\begin{array}{l}\chi^{2}=0,579 \\
p=0,447\end{array}$} \\
\hline & no & 17 & 2,6 & 633 & 97,4 & 650 & 90 & \\
\hline \multirow{2}{*}{$\begin{array}{c}\text { Pass } \\
\text { progglotid }\end{array}$} & yes & 2 & 14,3 & 12 & 85,7 & 14 & 1,9 & \multirow{2}{*}{$\begin{array}{l}\chi^{2}=7,029 \\
p=0,008\end{array}$} \\
\hline & no & 18 & 2,5 & 690 & 97,5 & 708 & 98,1 & \\
\hline \multirow{2}{*}{$\begin{array}{c}\text { Mouth } \\
\text { drooling }\end{array}$} & yes & 10 & 4,3 & 225 & 95,7 & 235 & 32,5 & \multirow{2}{*}{$\begin{array}{l}\chi^{2}=2,853 \\
p=0,091\end{array}$} \\
\hline & no & 10 & 2,1 & 477 & 97,9 & 487 & 67,5 & \\
\hline \multirow{2}{*}{ Nail bite } & yes & 6 & 4,4 & 130 & 95,6 & 136 & 18,8 & \multirow{2}{*}{$\begin{array}{l}\chi^{2}=1,677 \\
p=0,195\end{array}$} \\
\hline & no & 14 & 2,4 & 572 & 97,6 & 586 & 81,2 & \\
\hline \multirow{2}{*}{$\begin{array}{c}\text { Teeth } \\
\text { grinding }\end{array}$} & yes & 4 & 3,7 & 104 & 96,3 & 108 & 14,9 & \multirow{2}{*}{$\begin{array}{c}\chi^{2}=0,411 \\
p=0,521\end{array}$} \\
\hline & no & 16 & 2,6 & 598 & 97,4 & 614 & 85,1 & \\
\hline \multirow{2}{*}{$\begin{array}{l}\text { Enuresis } \\
\text { nocturna }\end{array}$} & yes & 5 & 10,2 & 44 & 89,8 & 49 & 6,8 & \multirow{2}{*}{$\begin{array}{c}\chi^{2}=10,786 \\
p=0,001\end{array}$} \\
\hline & no & 15 & 2,2 & 658 & 97,8 & 673 & 93,2 & \\
\hline \multirow{2}{*}{ Dysuria } & yes & 3 & 5,8 & 49 & 94,2 & 52 & 7,2 & \multirow{2}{*}{$\begin{array}{c}\chi^{2}=1,871 \\
p=0,171 \\
p>0,05\end{array}$} \\
\hline & no & 17 & 2,5 & 653 & 97,5 & 670 & 92,8 & \\
\hline \multirow{2}{*}{ Diarrhea } & yes & 1 & 4,0 & 24 & 96,0 & 25 & 3,5 & \multirow{2}{*}{$\begin{array}{l}\chi^{2}=0,145 \\
p=0,703\end{array}$} \\
\hline & no & 19 & 2,7 & 678 & 97,3 & 697 & 96,5 & \\
\hline \multirow{2}{*}{ Anorexia } & yes & 11 & 5,8 & 179 & 94,2 & 190 & 26,3 & \multirow{2}{*}{$\begin{array}{l}\chi^{2}=8,728 \\
p=0,003\end{array}$} \\
\hline & no & 9 & 1,7 & 523 & 98,3 & 532 & 73,7 & \\
\hline
\end{tabular}


Student who participated in research had abdominal pain, dropping ring, nocturnal enuresis. This situation was found significant to be statistically $(\mathrm{p}<0,05)$.

A control group who 20 healthy students had been gotten involved to compare with 20 students Enterobius vermicularis to search to alteration of blood value owing to Enterobius vermicularis. Blood count results from blood samples which have been taken from experiment group and control group have been obtained. Also results obtained from biochemistry and blood count values of students in control and experiment groups have been divided to be low, normal and high groups.

Statistically analysises of biochemistry results which have been obtained from blood samples that have been taken from children with enterobiosis and non enterobiosis have been done with Nonparametric Mann-Whitney test and difference of ALT, AST, Direct biluribin, gamma, sodium, uric acid, VLDL and total biluribin values was found significant statistically $(\mathrm{p}<0,05)$.

Blood count results of children enterobiosis and nonenterobiosis have been analyzed by being used Mann-Whitney test and HGB, HCT, MCHc, RDW, PLT, \%NEUT, \%EOS, \#LYM, \#EOS values were found ignificant to be statistically $(\mathrm{p}<0,05)$.

\section{DISCUSSION}

Intestinal parasites cause signs as abdominal pain, nausea, vomiting, appetite deviation, diarrhea, bloody diarrhea, weight loss, paining joint, dizziness, nocturnal enuresis, itching of the nose and anus, irritability, anemia, growth retardation. One of reasons of this alteration is diversity of diagnosis methods in prevalence of E.vermicularis ${ }^{7}$.

It has been reported in a case Turgay and Üstün ${ }^{8}$ informed parasite wasn't identified in a child Enterobiosis after doing stool examination. Akisu et al. ${ }^{9}$ have used only stool examination for method at done study on prevalence of intestinal parasite in primary school in İzmir-Narlıdere and found that the presence of E.vermicularis was $0,6 \%$ like quite low value.

E.vermicularis was found in different rates in anal band surveys that were been done by various researchers. Özcan et al. ${ }^{10}$ found E.vermicularis $38,97 \%$ in rate in some schools in Hatay, Metinbaş et al. ${ }^{11}$ found E.vermicularis $24 \%$ in rate in primary school students in Eskişehir, Özçelik et al. ${ }^{12}$ found E.vermicularis $31 \%$ in rate in students in Kırıkkale, Aşçı et al. ${ }^{2}$ found E.vermicularis $97,4 \%$ in rate in children at their study in Elazı̆g.

Giray and Keskinoğlu ${ }^{13}$ found prevalence of E.vermicularis was $43,8 \%$ in primary school children at their study in İzmir. Çulha et al. found 664 were taken from male, 1056 were taken from female of 1720 cellophane band examples at his study in Hatay and E.vermicularis was found in $65(\% 9,78)$ male and $85(\% 8,04)$ female in total 150 people ${ }^{14}$.

Özcan et al. ${ }^{15}$ found E.vermicularis in 16,1 $\%$ of total 607 students in four primary schools in Kayseri. Also, relationship between presence of parasite and parameters as school, sex, age, class, kind of house residing, source of water drinking, the number of people living in the house, abdominal pain, sleep disorders, dental gnashing, nasal itching, night terrors, coughing bouts, a singing in the ears, nocturnal enuresis, pruritus ani and distractibility has been investigated. But they haven't found connection between these parameters and presence of parasites significant statistically.

Hazır et al. ${ }^{16}$ found $10,9 \%$ in prevalence of Enterobius vermicularis at two primary schools with different socio-economic level at their study in Ankara. Also they have informed in parasite frequency in students in 8-9 age was higher $(14,7 \%)$ than parasite frequency in students in 6-7 age in students and in 6-9 age. Daldal et al. $^{17}$ found a logic relationship between age and presence of parasite. The incidence of parasite was observed in the most in $7-12$ age $(55,0 \%)$. E.vermicularis was found in the most in 7-9 age in our study.

Tamer et al. ${ }^{18}$ informed that the most intensive distrubition of positive cases according to 
distrubition of ages has been in 0-14 age and E.vermicularis and G.intestinalis have been in this age group intensively. This situation is important because of children haven't cleaning habits sufficiently, E.vermicularis infects to people from people easily and infected is seen with self-infection.

At the end of our research anorexia, flowing saliva and abdominal pain have been in the most meeting with clinic sign in infected children. Taşar et al. ${ }^{19}$ found Enterobius vermicularis has been in reasons of abdominal pain in his study.

In this work it was found that weight and length percentiles of children Enterobiosis and not were lower than control group statistically. This difference can be occured malnutrition being come up owing to parasitic diseases. Also it must be thought that different parasitic infections can will be occured in children who body resistance was low, have malnutrition and have different predispozing factors.

When connection between enterobiosis and blood values has been evaluated despite detailed researches and direct diagnosises haven't been reached about subject, it is also possible it can be said that situation specifing in classical sources was found at this study. As clarifing at some sources, because of multicellular parasites depending on their sizes have complex tissue and organs and active metabolism, they are face to face with an evident immune response of host. Metabolic products, enzymes and other secretory products of helminthes and protozoan are primarily antigens. Different evolution periods of a lot of helminthes developing have antigenic structure in this specific periods. Host response occurs against these antigens in different ways. Immunologically response was created by host against parasites reveals own in two ways. One of these is eosinophils, second of these is formation of IgE. Both of them occur depending on $T$ cell. In the scope of these information being fixed eosinophils in an evident quantity according to haven't intestinal parasites in chilren who we found Enterobius vermicularis consistents with cources ${ }^{20-26}$. In this work when blood eosinophils values of parasitic patient and not were compared, there was statistically significant differance. This result is parallel result to our information about increasing eosinophils coming across in parasitosis mostly.

Relationship among parasitosis and anemia and growth retardation which was proved also was obtained in this work. HCT value in 12 (\%60) of 20 patients enterobiosis has been obtained lower than normal value. Also growth retardation in children enterobiosis reveals own clearly.

As finding out example works, rates of intestinal parasites in our country's west areas where has better substructure possibilities are lower than east and south areas. Owing to Kocaeli is a developed industry city additionally developed city in terms of substructure status, has lower intestinal parasites than east cities. Intestinal parasites reveal to decreasing in the areas where have regular substructure. Değerli et al. ${ }^{7}$ reported that solutions of substructure problem together important dropping in parasite availability in Sivas. Tamer et al. ${ }^{18}$ found $\% 10,67$ in prevalence of parasite in 2003-2005 and in $\% 14,21$ of samples between 2001-2003 in Kocaeli ${ }^{26}$. This two rates reveal dropping of parasitosis in our area more and more.

Also bringing own habits of citizens who come from east and south east in Kocaeli that get immigration create risk.

In this work finding lower presence of parasite compared with the previous years shows that this decreasing indicates parallel with being informed of children and evolution of social consciousness it is an avoidable problem.

\section{REFERENCES}

1. Dinçer S, Koltaş IS, Kar Ş, Kazanıcı F, Özcan K,. Distrubition of Enterobius vermicularis in Kahramanmaraş Hundredth Year Primary and Güzelyurt Primary Schools, Turkish J Parasitol 1999; 23 : 137-8.

2. Aşçı Z, Yılmaz M, Ay $\mathrm{S}$, Barlas $\mathrm{H}$. Parasitological Examination in Harput Kindergarten in 6-12 Age Group 
Children. Turkish J Parasitol 1991; 15: 83-7.

3. WHO. It's a wormy world. Geneva. WHO/CTD/SIP/98.4.

4. Fan PC. Review of Enterobiasis in Taiwan and Offshoe Islands. J Microbiol Immunol Infect 1998; 31: 203-10.

5. Güryuva S,Aktaş M, Aydın G. Examining Of Patients Who Apply To Parasitology Laboratory Refik Saydam National Public Health Agency In Terms Of Intestine Parasites, Turkish J Parasitol 1998; 22: 32-6.

6. Değerli S, Malatyalı E, Özçelik S, Çeliksöz A. Enterobiosis in Sivas, Turkey from past to present, effects on primary school children and potential risk factors, Turkish J Parasitol 2009; 33: 95-100.

7. Değerli S,Özçelik S,Çeliksöz A. Distribution Of Intestine Parasites In Patients Who Apply For Cumhuriyet University Medical Faculty Parasitology Lab, Turkish J Parasitol 2005; 29: 116-9.

8. Turgay N, Üstün Ş,. Enterobiosis. Özcel MA. Medical Parasite Diseases. İzmir Beta Issue Typography. 2007, 729-34.

9. Akısü Ç, Özkoç S, Aksoy Ü, Sarı B, Prevalence Of Intestine Parasites In a Primary School in İzmir-Narlidere. Infect Journa, 2003; 17: 487-90.

10. Özcan K, Koltaş S, Tanrıverdi S, Yiğit S, Sadr YE. Discussion Of Intestinal Parasites In Some Primary Schools In Hatay. Turkish J Parasitol 1994; 18: 4618.

11. Metinbaş S, Kaya D, Sanboyacı MA, Kaya E. Frequency of Intestinal Parasites In Subprivate Class Students in Eskişehir, Turkish J Parasitol 1996; 20: 199-206.

12. Özçelik S, Poyraz Ö, Saygı G, Güneş T, Sümer Z, Çeliksöz A. Prevalence of Intestinal Parasites in Children Living in A Rural Section of Kirıkkale, Turkey, Turkish J Parasitol 1995; 19: 249-53.

13. Giray H, Keskinoğlu P. The Prevalence of Enterobius vermicularis In Schoolchildren And Affecting Factors. Turkish J Parasitol 2006; 30: 99-102.

14. Çulha G. The Distribution of Patients With Intestinal Parasites Presenting At The Parasitology Laboratory of The
Mustafa Kemal University Medical Faculty, Turkish J Parasitol 2006; 30: 302-4.

15. Özcan S, Özcan H, Sönmez E, Yazar S. Investigation of The Distribution Of Enterobius vermicularis In Four Primary Schools In Kayseri. Turkish J Parasitol 2004; 28: 24-6.

16. Hazır C, Gündeşli H, Özkırım A, Keskin $\mathrm{N}$, Distribution of Enterobius vermicularis Among The Schoolchildren of Two Primary Schools with Different Social-Economic Status in the Ankara Province, Turkish J Parasitol 2009; 33: 54-8.

17. Daldal N, Karaman Ü, Aycan ÖM, Çolak C, Miman Ö, Çelik T, Atambay M, Prevalence of Intestinal Parasitic Infections Among Nursery School and Orhpanage, Inonu University Medicine Faculty Journal 2007; $14:$ 231-5.

18. Tamer GS, Çalışkan Ş, Willke A,. Distribution of Intestinal Parasites Among Patients Who Presented At The Parasitology Laboratory Of The Kocaeli University School Of Medicine Hospital Turkish J Parasitol 2008; 32: 126-9.

19. Taşar MA,. Evaluation of Children With Abdominal Pain Gülhane Medicine Journal 2005; 47: 199-203.

20. Sayg1 G. Basis Medical Parasitology, 2. Edition, Es-Form Ofset Ltd. Şti, Sivas, 2002, S.127-131.

21. Unat EK, Yücel A, Altaş K, Samastı M. Unat's Medicine Parasitology, Eukaryotic Parasites and Diseases Forming Owing These of Person, Fifth Edition, İstanbul University Cerrahpaşa Medicine Faculty Foundation Publication:15, Cağaloğlu, İstanbul, 1995, S:289-97.

22. Değerli S, Çeliksöz A, Aslan A, Acıöz M, Özçelik S. Comparison of the Results of Examination of Fecal Samples from Students at Six Months Intervals in the Alahaci Village Primary School in Sivas, Turkish J Parasitol 2006; 30: 305-7.

23. Şenel S,Ozçelik S, Degerli S. Investigation of Intestinal of Relationship Between Parasitosis and Eosinophilia, Turkish J Parasitol 2002; 26: 274-7. 
24. Celiksoz A, Acioz M, Degerli S, et al. Effects of Enterobiasis on Primary School Children, African J Microbiol Res 2010; 4: 634-9.

25. Çeliksöz A, Acıöz M, Değerli S, Alim A, Aygan C. Egg Positive Rate of Enterobius vermicularis and Taenia sp. By Cellophane Tabe Method in Primary School Children in Sivas, Turkey, Korean J Parasitol 2005; 43: 61-4.

26. Tamer GS. Distribution of Intestinal Parasites Among Patients Who Presented At The Parasitology Laboratory of The Kocaeli University School Of Medicine Hospital, XIII. National Parasitology Congress Program and Summary Book, 2003, S.221. 